\title{
THE EFFECT OF DIFFERENT PRE-WEANING DIETS AND FEEDING METHODS ON SURVIVAL RATE OF ELVERS, ANGUILLA ANGUILLA
}

\author{
O.M. El Hussieny ${ }^{1}$; A.M. Abd-El Samee. ${ }^{2}$; A.M.A.Ghonimy ${ }^{3}$ and Rania S. Mabroke ${ }^{1}$ \\ ${ }^{1}$ Animal Production Department, Faculty of Agriculture, Cairo University, Egypt \\ ${ }^{2}$ Fish Nutrition Laboratory, National Institute of Oceanography And Fisheries(NIOF), Cairo, Egypt \\ ${ }^{3}$ Aquaculture Food and Feeding Department, Fish Farming and Technology Institute, Suez Canal \\ University, Ismailia, Egypt.
}

(Received 10/1/2016, Accepted 6/3/2016)

SUMMARY

\begin{abstract}
$\mathrm{W}$
eaning period is the most critical period of eel life stages where high mortality rate occurred as a consequence to transfer into artificial diet .The study included two experiments to examine the pre-weaning diet and feeding methods effects on survival rate of eel fish.The first experiment examined the effect of beef liver (BL), tubifex worms (Tubifex spp.) (TW) and the mix (BL+TW) as preweaning diet on survival rate and weaning period.While, the second experiment examined four feeding methods, aquarium bottom method (ABM), floating net method (FNM), rubber pipe method (RPM) and feeding chamber method (FCM) for their convenient for elvers feeding, survival and limitation of feed loses. Results suggested that elvers fed (TW) observed for the highest survival rate and the longest weaning period.Feeding chamber method (FCM) is the most convenient for elvers feeding as recorded the highest survival rate and lowest feed losses.
\end{abstract}

Keywords: pre-weaning, Anguilla anguilla, survival rate, tubifex worms, feeding method.

\section{INTRODUCTION}

In Egypt as many developing countries, aquaculture sector recently plays a crucial role in covering the protein requirement gape. Currently, farmed species are few and the market diversification represents an interesting strategy to aquaculture sector (El-Shebly et al. , 2007). In particular it is necessary focus on species with a high market value such as eel fish. The global production of eel fish was 210303 tons in 2001, and it increased about 29\% in 2010 (FAO, 2012). The top three producing countries of farmed European eel are Netherlands, Italy and Denmark (FAO, 2012).In Egypt, eel fish has an high market value. Moreover, Egypt has the advantage of having an appropriate environment for eel culture; the optimum of growth occurs at a temperature of 24-26 (FAO, 2006). However, eel fish have many management problems as the acceptance of artificial feed (weaning), escaping behaviors, high mortality rate and feed costs. High mortality rate occurs during the weaning to artificial diet and only the $25-40 \%$ of population reaches the market Table size (Larkin, 2000). The first twelve weeks of feeding is the most critical period in the rearing cycle. The mortality rate may reach the 30-70\% (Degani and Levanon, 1983). The limited success in the culture of glass eels is due in part to the unsuitability of diets and, also to an inadequate knowledgeof the development of the digestive system during the transition from the glass eel to elver stage (Rodriguez, et al., 2005).The aim of the study was to find out the optimal pre-waning diet and feeding method for elver eel to decrease feed losses which improve water quality and decrease water substitution, subsequentlyimproving survival rate.

\section{MATERIALS AND METHODS}

Glass aquaria $(80 \times 40 \times 60 \mathrm{~cm})$ of 100 Lcapacity were used. Specialtubes $(20 \mathrm{~cm}$ each) were kept inside aquarium to provide an adequate resting area (Tesch, 2003). Aquaria were supplied with well 


\section{El Hussieny et al.}

water which was exchanged, once daily, after the second feeding time. The aquaria were equipped with an air pump to permit water oxygenation.Aquaria were covered with black plastic sheet to obtain a semi-darkness condition, which is important for elvers growth (Larkin, 2000). Elver eel Anguilla anguilla were caught in Edku lake, Alexandria, Egypt and carefully transferred to the laboratory. On arrival, they were checked for health status and acclimatized to laboratory conditions for 4 days (Larkin, 2000).

\section{EXP. (I): The effect of different pre-weaning diets on survival rate and weaning period of elvers}

Three different animal protein sources: beef liver(BL), Worms (TW) (Tubifex spp.) and 50\% BL + $50 \%$ TW were used as pre-weaning diets to study their effect on the length of weaning period and the survival rate. Pre-weaning diets were prepared differently before to be administered to elvers. Frozen beef liver was minced andconnective tissues were eliminated. Live worms were delivered without any preliminary treatment. Minced beef liver was mixed with live worms. Single weaning diet (Table 1) was formulated to substitute $5 \%$ of weaning diet to avoid weaning shock (Larkin, 2000). Substitution percentage was increased gradually $(20 \%)$ up to $100 \%$ weaning diet. Increasing inclusion of weaning diet in elver ration depended on survival rate results of each treatment during the experimental period. Elver eel Anguilla Anguilla(0.66g, SD=0.02) were distributedinto nine experimental aquaria (40 elvers/ aquarium).Each of the pre-weaning diet treatments was triplicated, the experimental diets were introducedtwice daily $(8: 00 \mathrm{am}$ and $2: 00 \mathrm{pm})$ and feeding rate were estimated according to apparent satiation. Feed intake (FI) and survival rate were the main parameters estimated during the experimental period (42 days).

\section{Table (1). Formulation, chemical analysis of weaning diet}

\begin{tabular}{|c|c|}
\hline Item & weaning diet \\
\hline \multicolumn{2}{|l|}{ Ingredient $\%$} \\
\hline Fish meal & 61 \\
\hline Corn glutin & 7 \\
\hline Bran & 6.9 \\
\hline Starch & 14 \\
\hline $\mathrm{CMC}^{*}$ & 3 \\
\hline Fish oil & 2 \\
\hline Soybean oil & 2 \\
\hline Vit. +Min. premix $* *$ & 4 \\
\hline Vitamin $\mathrm{C}$ & 0.1 \\
\hline \multicolumn{2}{|c|}{ Chemical Composition Determination \% } \\
\hline Ether Extract & 13.0 \\
\hline Crude protein & 45.5 \\
\hline Ash & 9.0 \\
\hline Total Carbohydrates & 26.5 \\
\hline $\mathrm{GE}(\mathrm{Kcal} / \mathrm{Kg})$ & 4872 \\
\hline
\end{tabular}

\section{EXP. (II): The effect of different feeding methods on elver survival and feed intake}

Elver feeding behavior causes the dispersal of feed all over the aquaria water, becauseof fast movementsduring feedingtime. This feeding behavior causes feed losses and reduces water quality of the aquaria.Weaned elvers $(0.71 \mathrm{~g}, \mathrm{SD}=0.03)$ were pooled and randomly re-distributed in 12 aquaria (20 elver/aquarium). Four different feeding methods:aquarium bottom method (ABM), Floating net method (FNM), Rubber pipe method (RPM) and Feeding chamber method (FCM) were examined for their efficacy in the feeding behavior of elvers for ten days. Elvers in all experimental treatments were fed with 5\% of their body weight on a single diet (basal diet, Table1) twice daily (8:00 am and 2:00 pm). Feed were introduced using one of the following feeding methods. (1) Aquarium bottom methods (ABM): elvers were fed on feed paste introduced in the aquarium bottom; (2) Floating net methods 
(FNM): diet paste was introduced in a floating plastic net, that have holes of $1 \mathrm{~cm}$ in diameter;(3) Rubber pipe method (RPM): diet paste was introduced in a cylindricalrubber pipe (1/2 inch) with two half cylindersat the ends (fig. 1). The structure of the rubber pipe guarantees its stability in aquaria bottom and as a feed keeper; (4) Feeding chamber method (FCM): a feeding chamber was designed to represent an isolated place for feeding of eel and to avoid water aquaria contamination with feeding wastes. .Feed paste was introduced in the rubber pipe inside the chamber (fig. 2). A plastic bottle was the main part of feeding chamber. Elvers used to get inside the chamber from an entrance covered with a piece of gauze with two fixed ends (one end was fixed by bottle cap and the other end byrubber band under the bottle entrance). Feeding residues were collected by a siphon after half hour of feeding according to Lee, and Bai, (1997) and dried at 60-70 ${ }^{\circ}$ overnight.

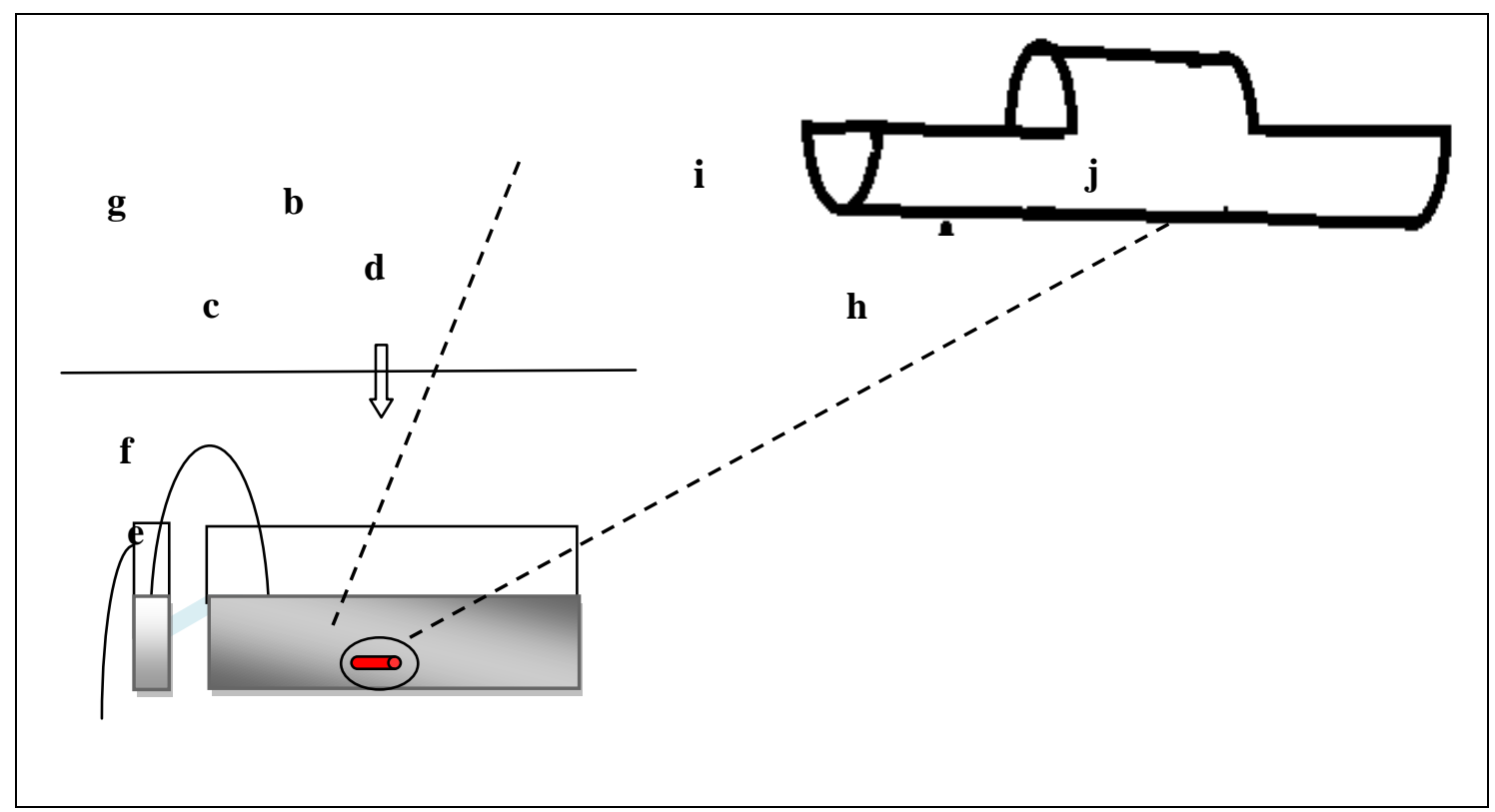

Fig. (1). Rubber pipe feeding method (RPM). Aquarium (a), water (b), water line supply(c), water tap (d), water connection tube (e), equilibrium bottle (f), outlet tube (g), rubber pipe (h), feed part (i) and equilibrium part (j).

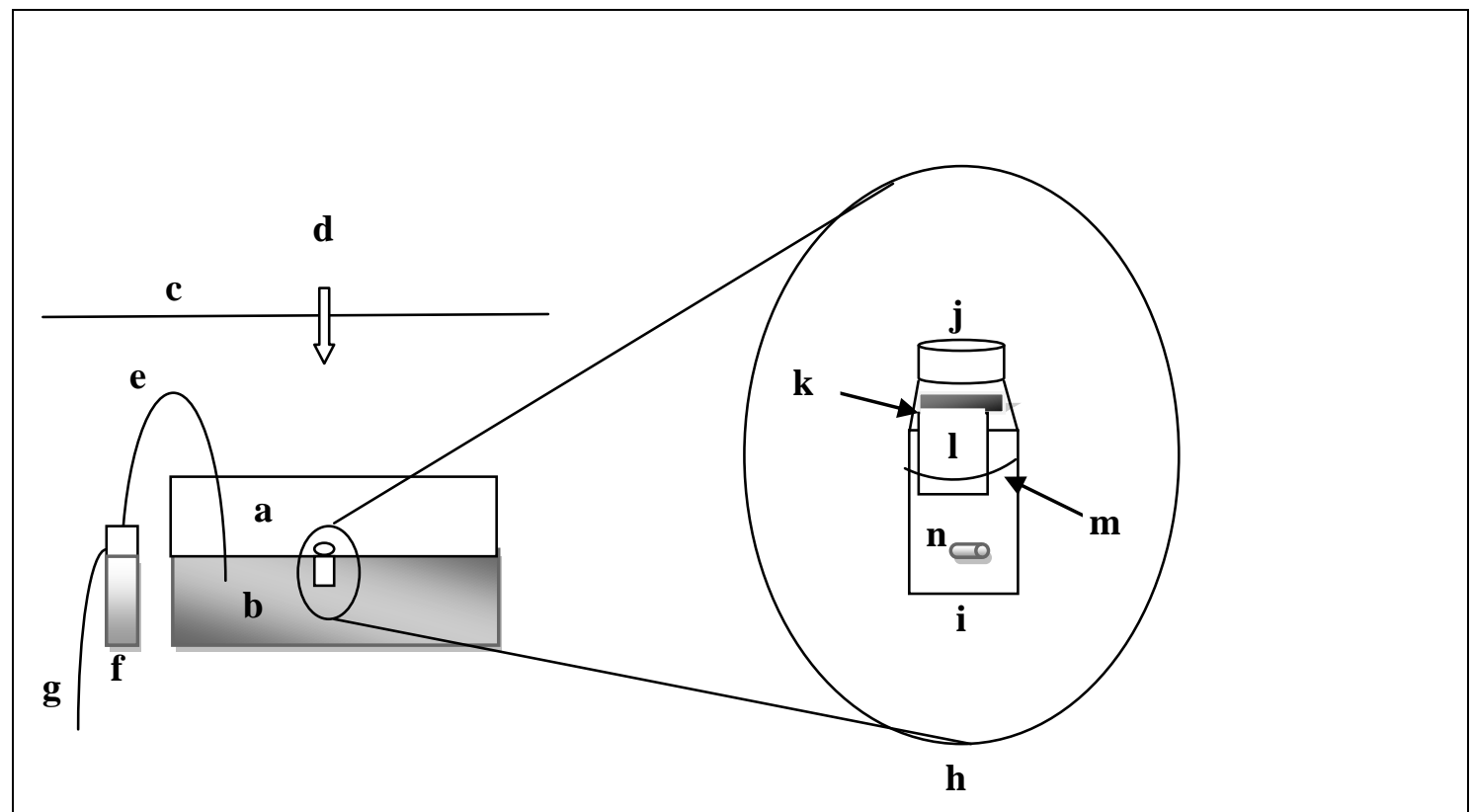

Fig. (2). Feeding chamber method (FCM). Aquarium (a), water (b), water line supply(c), water tap (d), water connection tube (e), equilibrium bottle (f), outlet tube (g), feeding chamber (h), bottle (i), bottle cap (j), chamber entrance (k), gauze (l) Rubber band (m) and the rubber $\operatorname{pipe}(\mathbf{n})$ 
The results of the experiments were statistically analyzed by one-way ANOVA, using a computer software application of SAS version 9 (SAS Institute Inc., 2004) program. Data was analyzed by analysis of variance in GLM procedure in SAS. Duncan's new multiple range test was conducted to determine the significant differences between data generated (Duncan, 1955).

\section{RESULTS AND DISCUSSION}

The main obstacles which face eel culture are relative toweaning of glass eels and early elvers with a suitable dry diet. High mortality rate (30-70\%) occurred during the first three months after capture because not all eels adapt to artificial diets (Degani and Levaron, 1983).First feeding of elvers in culture conditions has often been found to be a period of high mortality (Peterson and MartinRobichaud, 1994). In the early stages of elver weaning a high survival rate is directly related to the ability to feed on artificial diets, while, in this phase, the growth is less important (Larkin, 2000). The effect of pre-weaning diets in terms of weaning time, survival ratesand feeding methodisnotpreviously been considered. The efforts in this study were dedicated to understand elvers feeding behavior during this stage because considered a possible strategy of management to avoid a high mortality rate.

\section{EXP. (I): The effect of pre-weaning diets on survival rate and weaning period of elvers}

Elvers responded differently to pre-weaning diets (BL, TW and BL+ TW) in terms of feed intake of pre-weaning and weaning diets, survival rate and weaning period, which were summarized in Table (2). The higher intake of pre-weaning diets was recorded $(\mathrm{P} \leq 0.05)$ for elvers fed on $\mathrm{TW}$ followed by those fed on BL+TW, while, the lowest value was noticed for BL treatment.

\begin{tabular}{|c|c|c|c|c|}
\hline Criterion & $\mathrm{BL}$ & TW & $\mathrm{BL}+\mathrm{TW}$ & $\mathrm{SE} \pm$ \\
\hline Pre- weaning diet intake (g) & $127.40^{c}$ & $250.80^{\mathrm{a}}$ & $200.00^{b}$ & 2.18 \\
\hline Weaning diet intake $(\mathrm{g})$ & $54.40^{c}$ & $85.20^{\mathrm{b}}$ & $96.89^{\mathrm{a}}$ & 0.86 \\
\hline Survival rate (\%) & $60.00^{c}$ & $85.00^{\mathrm{a}}$ & $64.00^{\mathrm{b}}$ & 0.55 \\
\hline Weaning period (days) & 35.00 & 42.00 & 35.00 & - \\
\hline
\end{tabular}

Survival rate followed the same trend of pre-weaning diet intake with the highest value $(\mathrm{p} \leq 0.05)$ was reported for TW, while, BL recorded the lowest survival rate (fig. 3). Results suggested that 42 days are necessary to wean elvers fed on TW as pre-weaning diet, while only 35 days are needed for elvers fed on either BL or BL+TW (Fig. 4). First inclusion of weaning diet (5\%) in elver ration under TW treatment reported the longest adaptation period (14 days) compared to other treatments or other substations stages (Fig.4). Overall, TW recorded the highest pre-weaning diet intake, lowest mortality rate and the longest weaning period.

As previously clarified, pre-weaning diet affects both survival rate and weaning period. TW seems to be preferred by elvers thus it took longer to transfer elver to weaning diet. It was noticed that the live diet is more attractive to elvers (Larkin, 2000). In the same context Croy and Hughes, (1991) reported that eel prefers prey animals that are suited to its body size and can be caught. It was used to feed glass eel with Artemia, later supplemented with Daphnia and oligochaete worms (Tubifex spp. and Lumbriculus spp.) and gradually weaned from these onto a suitable dry diet (De Silva et al., 2001). Some early studies as, Degani et al. (1984), also, suggested that glass eels were more attracted to raw meal than artificial feed which led to improving growth and survival rate. On this basis some breeders begin feeding with tubifex or invertebrate as pre-weaning diets (Degani and Levaron, 1983). It was suggested that during initial adaptation period, feeding artificial feed with raw meat improved growth 
performance (Degani and levanone., 1986.). Afterward, it was used in Europe and Australia diets with roe of the Atlantic cod and carp roe, before switch to a dry diet (De Silva et al., 2001). It was also suggested that glass eel fed on Artemia and minced fish flesh showed better growth performances than those fed on liver /fines mix and trout fines (Larkin, 2000)

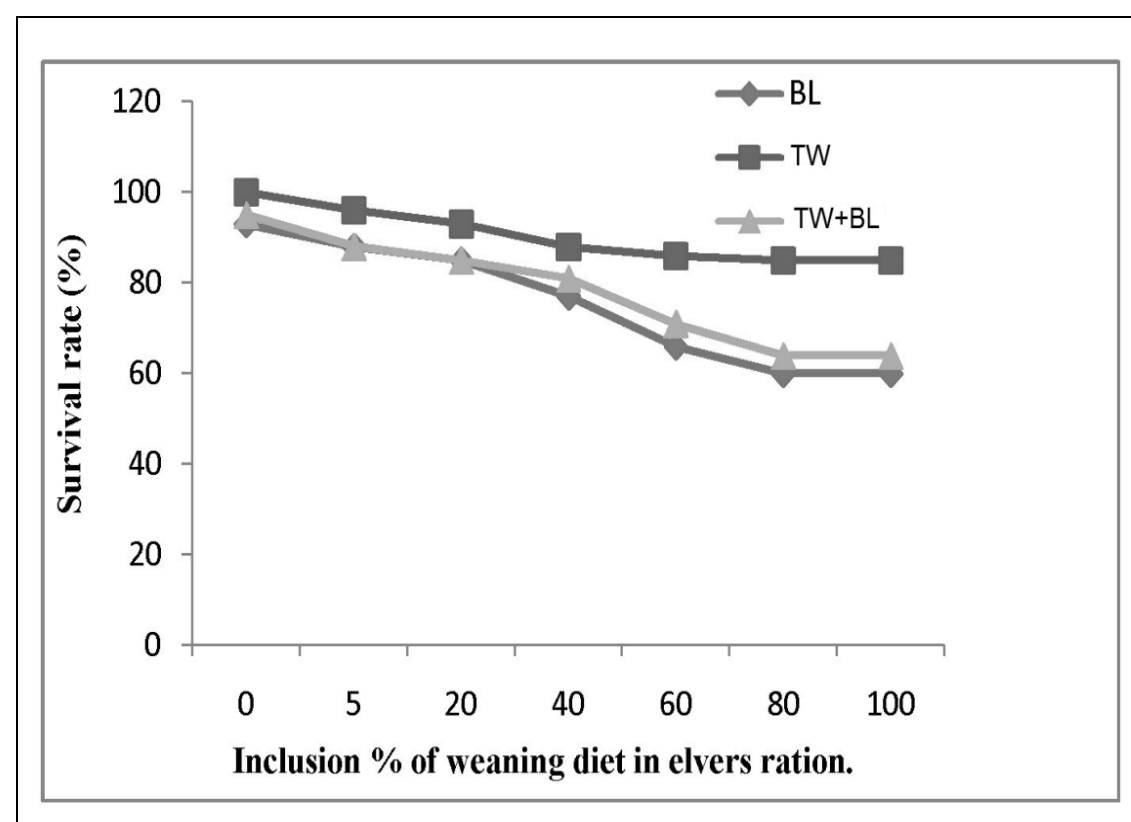

Fig. (3). Effect of different pre-weaning diets and their gradually substations on elvers survival rate during experimental period

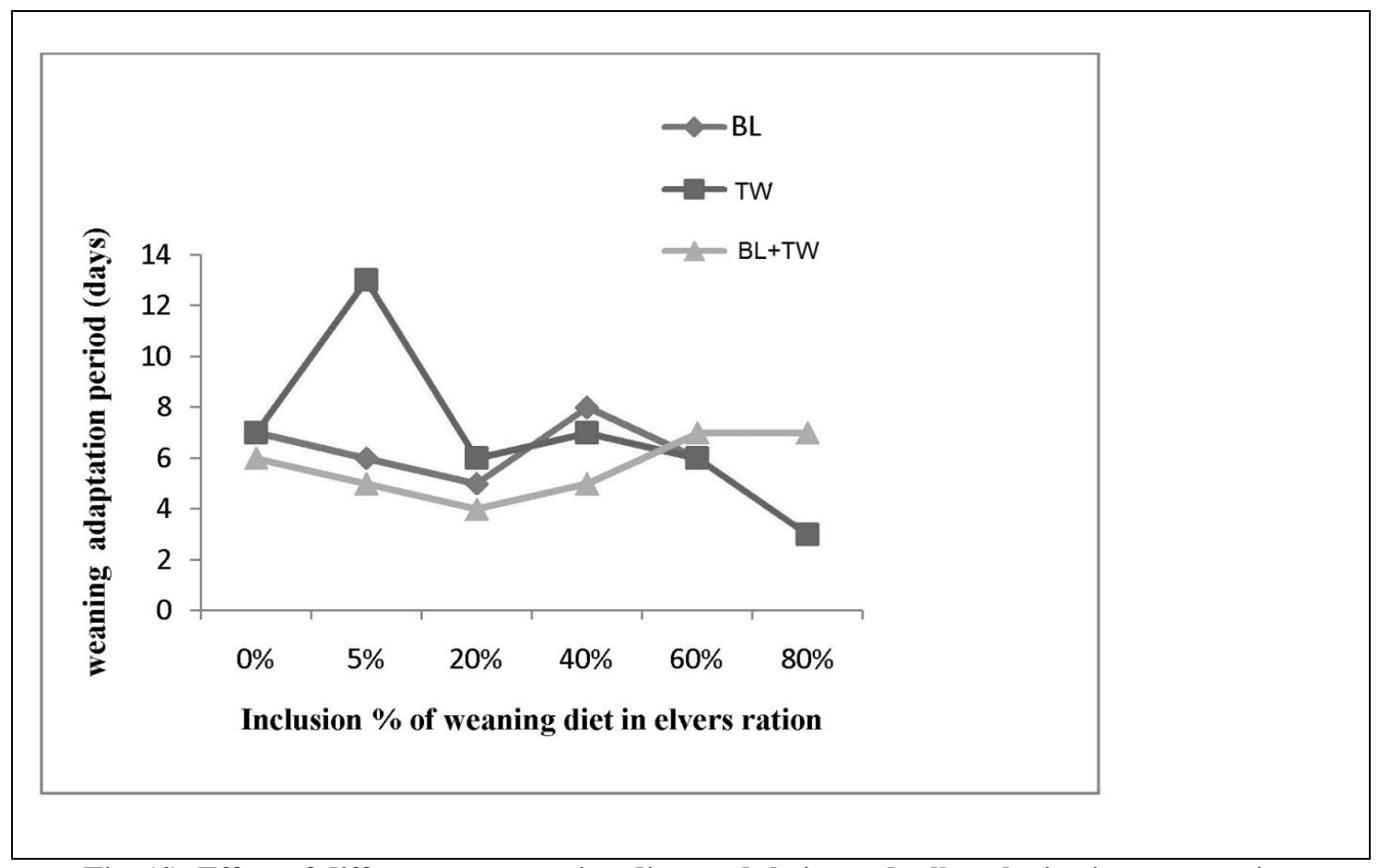

Fig. (4). Effect of different pre-weaning diets and their gradually substitution on weaning adaptation period 


\section{El Hussieny et al.}

The reason of the long weaning period for eel fed on TW is that substitution of worms in the diet is more difficult than other pr-weaning diets. The worms are, in fact, the nearest food to the wild one of eels. Better palatability was observed for TW compared to other pre-weaning diets.Palatability may be the key factor in these results; the high mortality rate reported in the previous studies during the early life stages of eel could be a result of either inadequate or unattractive for elvers (Peterson and MartinRobichaud, 1994). Glass eel is highly attracted by food constituted by short chain amino acids as alanine and glycine (Sola et al.,1993). Alanine, represented between 23,1\% and 41,8\% of the total free amino acid pool of freshwater sludgeworms (L. hoffmeisteri, T. tubifex, Potamothrixmoldaviensis, P. vejdovskyi and Stylodrilusheringianus)(Graney et al. 1986).Saglio et al., (1990) found that the combination of alanine, valine and glycine showed significant effectson both attraction and exploration of carp(Cyprinuscarpio) similarly to the crude tubifex extract.

Low feed intake noticed for BL treatment, may be due to the propensity of the diet to cloud the water. T. tubifex could be considered as the carotenoid source because it contains about $15.02 \mathrm{mg} \mathrm{kg}^{-1}$ (Yanar et al., 2003).About40 $\mathrm{mg} \mathrm{kg}^{-1}$ areneeded in fish diets to ensure their pigmentation.

Different feeding behavior for elver in different treatments was noticed during the experimental period. For BL diet, eel detect the food, orient, approach, s-band shape of the eel body, ingest food item, backward and turn away. While, for TW type, eel noticed to have a behavior sequence started with detect the food, orient, approach, s-band shape of the eel body, hold worm, grasp, chew, backward and turn away. Fish fed BL+TW showed behavior sequence of feed detection, orient, approach, s-band shape of the eel body, chew food item, backward and turn away. We recorded another notice concerning with feeding time. The shortest feeding time was also noticed for BL and BL+TW (Table 2).

Physical nature of each pre-weaning diet could explain the notice of different feeding time or behavior of elver. As for (BL) its viscous texture and stability in water with no resistances lead to the direct ingestion of its particles, while the hold, grasp and chew sequence were noticed for live TW because of their movement resistance. For (BL+TW), fish showed a chew behavior because the BL viscously reduced the TW movement so, it could concluded that elver found that feeding on this mixture was easier than feeding on TW.

It could be concluded that during the initial adaptation period of elver, selection of proper preweaning diet may affect the whole weaning process in term of survival rate and weaning duration.

\section{Exp.(II): Effect of different feeding methods on elvers survival and feed intake}

Elvers weaning diet delivered using different feeding methods ABM, FNM, RPM and FCMshowed significant different values for feed residuals, real feed intake and survival rate (Table3).

Table (3). Effect of different feeding methods on feed intake, feed residuals and survival rate of elver (wet/ dry basis)

\begin{tabular}{lccccc}
\hline Criterion & ABM & FNM & RPM & FCM & SE $\pm^{*}$ \\
\hline Feed intake $(\mathrm{g})$ & $15.7 / 7.1$ & $15.7 / 7.1$ & $15.7 / 7.1$ & $15.7 / 7.1$ & - \\
Feed residual $(\mathrm{g})$ & $8.6^{\mathrm{a}} / 2.6^{\mathrm{a}}$ & $5.9^{\mathrm{b}} / 1.9^{\mathrm{b}}$ & $2.6^{\mathrm{c}} / 0.85^{\mathrm{c}}$ & $2.0^{\mathrm{d}} / 0.71^{\mathrm{c}}$ & $0.12 / 0.11$ \\
Real feed intake $(\mathrm{g})$ & $7.1^{\mathrm{c}} / 4.4^{\mathrm{c}}$ & $9.8^{\mathrm{b}} / 5.1^{\mathrm{b}}$ & $13.1^{\mathrm{a}} / 6.2^{\mathrm{a}}$ & $13.7^{\mathrm{a}} / 6.3^{\mathrm{a}}$ & $0.87 / 0.75$ \\
Survival rate $(\%)$ & $72^{\mathrm{d}}$ & $84^{\mathrm{b}}$ & $81^{\mathrm{c}}$ & $92^{\mathrm{a}}$ & 0.51 \\
\hline *SE \pm standard error. Calculated from residual mean square in the analysis of variance. A,,$\ldots . .$. etc. $_{\text {means }}$ in the \\
same row with different superscription are significantly different $(P \leq 0.05)$.
\end{tabular}

As shown in Table (3), aquarium bottom method (ABM) resulted in the highest feed loses, while the lowest value was recorded for feeding chamber method (FCM). The FCM showed the highest real feed intake and survival rate compared to other feeding methods. It assumed that feeding method defiantly play the major role in decreasing feed loses and in sequent improve water quality and survival rate. The wasted feed in the water column affect water quality. Different feeding behaviors were recorded for elvers under examined feeding methods. Elvers fed from aquarium bottom (ABM) used to attack feed pasts to hold parts then little backward (attacking many times continuously) that resulted in spreading of feed in the water body.Eel feeding behavior lead to spread feed waste in water body. Decrease in available feed for other individuals may cause an elevation in mortality rate 
(Table4). Fish fed with floating net method (FNM) found some difficulty in reaching feed, however an improvement in survival rate was recognized. Both rubber pipe method (APM) and feeding chamber method (FCM) act as feed saver and decrease feed spreading in aquarium water. It was obvious that FCM was more effective as an isolated area for feeding elvers than RBM. Aquarius water clarity was recognized for FCM as feeding residuals trapped inside the feeding chamber meanwhile, real feed intake and survival rate was improved. The eel effectively utilized the floating mesh as a habitat (Larkin 2000)

\section{ACKNOWLEDGMENTS}

This work was supported by National Institute of Oceanography and Fisheries (NIOF), Cairo, Egypt.

\section{REFERENCES}

Croy, M.I. and R.N., Hughes (1991). The role of learning and memory in the feeding behavior of the fifteen-spined stickleback, SpinachiaspinachiaL.. Anim. Behav., 41:149-159.

Degani, G. and D.,Levaron, (1983). The influence of low density on food adaptation cannibalism and growth of eel (Anguilla anguilla (L.)).Bamidgeh, 35:53-60.

Degani, G., D., levaron and G., Trigger (1984).Preliminary Study on the influence of different feeds on Mortality and growth of eels Anguilla anguillain the initial period. Bamidgeh,36:47-52.

Degani, G. and D.,Levanon (1986). The influence of different feeds on growth and body composition of glass eel (Anguilla australis).Bamidgeh,38(1)13-21.

De Silva, S.S., R.M.,Gunasekera,B.A., Ingram, and , J.L., Dobson (2001). Weaning of Australian shortfin glass eels (Anguilla australis): a comparison on the effectiveness of four types of fish roe. Aquaculture, 195:133-148.

Duncan, D.B. (1955). Multiple range and multiple F tests.Biometrics, 11(1).

El-Shebly, A.A.,M.A.H., El-Kady and , Md.Y., Hossain (2007). A Preliminary Observation on the Pond Culture of European eel, Anguilla Anguilla (Linnaeus, 1758) in Egypt: Recommendation for Future Studies. Pakistan journal of biological sciences, 10(7):1050-1055.

Graney, R.L., T.J., Keiltyand J.P., Giesy(1986). Freeaminoacidpools of five speciesof fresh water oligochaetes.Canadian Journal of Fisheries and Aquatic Sciences, 43, 600- 607, C.F., http://stopfake.ucoz.com/news/sludgeworms tubifex tubifex/2013-06-04170\#sthash.5TYXmkdN.zYP7gFG6.dpuf.Cited 4 June 2013.

FAO (2006). Cultured Aquatic Species Information Programme (CASIP).

FAO (2012).Fishery information, data and statistics website.Aquaculture production, 1984-2004.

Larkin, B. (2000).The Weaning and Growth of Anguilla australis Glass Eels and Elvers.Thesis, Deakin University.

Peterson, R. H. and D. J., Martin-Robichaud(1994).First feeding and growth of elvers of the American eel (Anguilla rostrata (Lesueur)) at several temperature regimes.Canadan technical report of fisheries and aquatic science No.2013 Department of Fisheries and Oceans Biological Station St. Andrews, New Brunswick

Rodruigez, A.,E., Gisbert and F.,Castello-Orvay (2005). Nutritional condition of Anguilla Anguilla starved at various salinities during the elver phase. Journal of Fish Biology, 67:521-534.

Saglio P., B., Fauconneau andJ.M., Blanc (1990). Orientation of carp, Cyprinmcarpio L., to free amino acids from Tubifex extract in an olfactometer. Journal of Fish Biology 37, 887-898. (Abstract)

SAS Institute Inc. (2004)SAS/STAT User's Guide. Version 9.1, Cary, NC: SAS Institute Inc. 
Tesch, F.W.(2003). The eel (Ed. 3) Blackwell publishing company Ltd,9600 Garsington Road,Oxford OX4 2D Q,UK,408 p.

Yanar M., Y., Yanar and M., AyçeGenç(2003).Tubifextubifex Müller, 1774 (Annelidae)'in besinkompozisyonu. E.U. Journal of Fisheries \& Aquatic Sciences20, 103-110.

تأثير اختلاف عليقة ما قبل الفطام وطرق التغذية على معدل الاعاثة لصغار ثعابين السمك الاوروبية

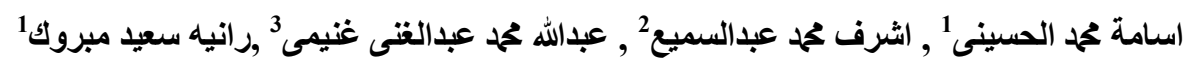

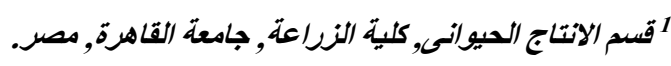

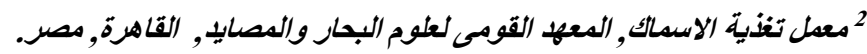

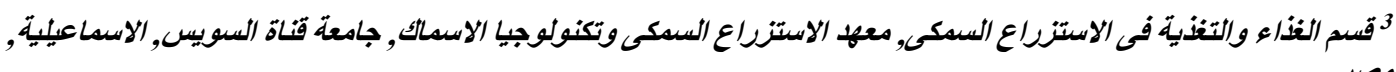

فترة الفطام من اكثر فتر ات حياة سمكة الثعبان خطورة ,حيث ترتفع نسبة النفوق عند انتقال السمكة الى العليقة

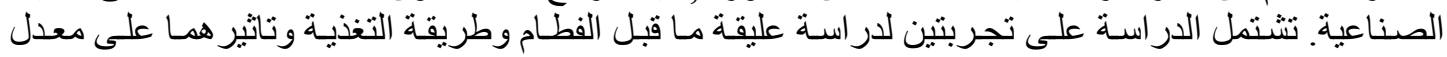

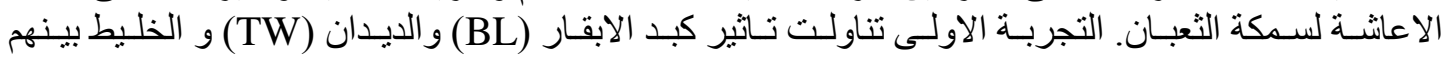

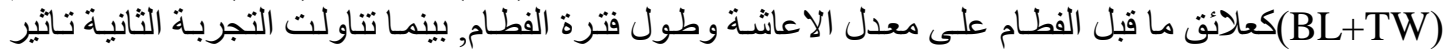

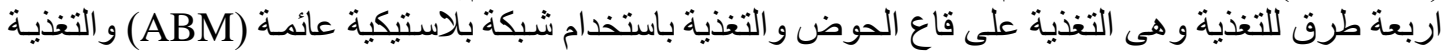

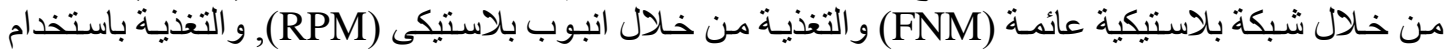

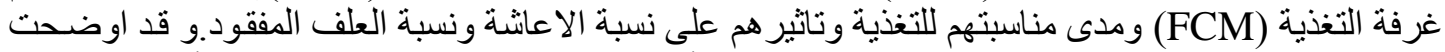

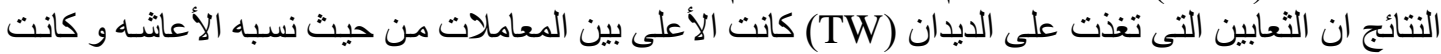

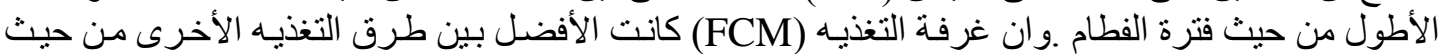

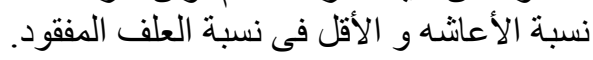

الكلمات المفتاحية: علائق ماقبل الفطام, سمكة الثعبان الاوروبية, معدل الاعاثَة, الديدان, طريقة التغذية. 